\title{
Analysis of diagnostic value of cytological smear method versus cell block method in body fluids with clinical and biochemical correlation: study of 150 cases
}

\author{
H. Chandan R. ${ }^{1}$, Pawar S. ${ }^{2 *}$, Reddy P. ${ }^{3}$ \\ DOI: https://doi.org/10.17511/jopm.2021.i01.02
}

\footnotetext{
1 Rajesh H. Chandan, Professor, Department of Pathology, Karnataka Institute of Medical Sciences, Hubballi, Karnataka, India.

2* Sumana Pawar, Post graduate student, Department of Pathology, Karnataka Institute of Medical Sciences, Hubballi, Karnataka, India.

3 Purushotham Reddy, Professor and Head of the department, Department of Pathology, Karnataka Institute of Medical Sciences, Hubballi, Karnataka, India.
}

Background: Aspiration of serous cavities is a simple and relatively non-invasive technique to achieve diagnosis. Cytological evaluation of body cavity fluid is diagnostically challenging. Especially in malignant effusions, helps in staging, prognosis and management of the patients. Aims: To assess the utility and sensitivity of cell block method over conventional smear technique in cytodiagnosis of the serous effusions. And to assess the utility and sensitivity of cytological evaluation of body fluids with biochemical and clinical correlation. Methods: A total of 150 fluid specimens were examined for conventional cytological smear (CS) and cell block method (CB). Out of 150 fluids, 96 were pleural fluid, 48 were ascitic fluid, 04 fluid from pouch of Douglas and 01 was from synovial fluid. Results: In this study, the utility of the CB method in the cytodiagnosis of malignant effusions was found to be highly significant as compared to the CS method. The additional yield of malignancy was $12 \%$ more as was obtained by the CB method. Conclusion: For the final cytodiagnosis of body fluid, there is statistically significant difference between the two techniques. In other words, CB is superior to CS method. It gives more information about the architectural arrangement and the likely source of primary. More important is that diagnostic material in cell blocks is available for special studies for Immunohistochemistry which can further supplement our knowledge about the primary source of metastasis.

Keywords: Cell block, Conventional Smear, Cytodiagnosis, Effusion

\section{Corresponding Author}

Sumana Pawar, Post graduate student, Department of Pathology, Karnataka Institute of Medical Sciences, Hubballi, Karnataka, India.

Email: sumanapawar@gmail.com

\section{How to Cite this Article}

Chandan RH, Pawar S, Reddy P. Analysis of diagnostic value of cytological smear method versus cell block method in body fluids with clinical and biochemical correlation: study of 150 cases. Trop J Pathol Microbiol. 2021;7(1):9-16.

Available From

https://pathology.medresearch.in/index.php/jopm/ar ticle/view/492
To Browse

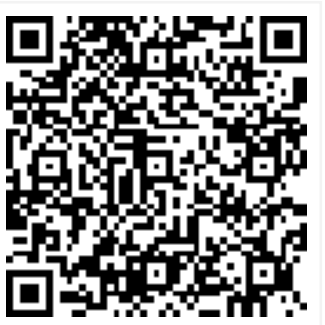

Manuscript Received 2020-11-03

Conflict of Interest No
Review Round 1 2020-11-13

Funding

Nil

Review Round 2
$2020-11-23$
Ethical Approval
Yes

Review Round 2

Yes
Review Round 3

Plagiarism X-checker $6 \%$
Accepted 2021-01-28

Note

(C) 2021 by Rajesh H. Chandan, Sumana Pawar, Purushotham Reddy and Published by Siddharth Health Research and Social Welfare Society. This is an Open Access article licensed under a Creative Commons Attribution 4.0 International License https://creativecommons.org/licenses/by/4.0/ unported [CC BY 4.0]. 


\section{Introduction}

Serous inflammation is called when the outpouring of a thin fluid which may be derived from the plasma or from the mesothelial cells lining the peritoneal, pleural or pericardial cavities. Accumulation of fluid other than blood in these cavities is called as effusion, which in the abdomen is called as ascites [1]. Serous effusions are called when accumulation of fluid in excess of the normal small amount in serous cavities [2]. These effusions are classified into two types- transudates and exudates. The transudates are clear, straw-colored fluids characterized by a low specific gravity oftenless then 1.010 and low protein content (Usually below $3 \mathrm{~g} / \mathrm{dL}$ ). It is due to increased venous pressure as seen in congestive heart failure or cirrhosis of liver and decreased oncotic intravascular pressure as seen in hypoproteinaemia, nephrotic syndrome. The exudates are characterized by relatively high protein content (Usually above 3 $\mathrm{g} / \mathrm{dL}$ ) and therefore a high specific gravity more than $1.015[2,3]$.

Cytological study of body fluid is a complete diagnostic modality. The information provided by body fluid analysis serves several functions. First, it assists the clinician in formulating and pointing out the aetiology of effusion and list of differential diagnoses. Second, it allows one to follow the results of therapy and the prognosis. The accurate identification of cells as either malignant or reactive mesothelial cells is a diagnostic problem in conventional cytological smears. Distinguishing benign from malignant cellular changes may require meticulous screening, careful scrutiny of cellular features and an understanding of the range of reactive changes. Due to cellular overlapping, delaying artifact, suboptimal processing, preparatory cytotechnique and leaving behind useful material causes lower diagnostic yield in Conventional Smear (CS) method. This residual material can be very useful in increasing diagnostic yield by the cell block method. The cell block (CB) technique is one of the oldest and complementary methods for the evaluation of body cavity fluids [4]. Cell block preparation increases the sensitivity of detecting malignancies, and also has the ability to reduce false-positive interpretations. A new method of cell block preparation by using $10 \%$ alcoholformalin a fixative was used to identify the sensitivity of the diagnosis in comparison with the conventional smear study.
This method is so simple and inexpensive which requires no extra material compared to other methods. The main advantages of the $\mathrm{CB}$ technique are preservation of tissue architecture and obtaining multiple sections for special stains and immunohistochemistry [5].

In this study, we have assessed and compared the utility of cell block and conventional smear technique in the cytodiagnosis of malignant effusion.

\section{Aims}

The aim of this study is to compare the cytomorphological features of the serous effusions by cytological smear method and cellblock method and also to assess the utility of combined approach for cytodiagnosis of these effusions. And to assess the utility and sensitivity of cytological evaluation of body fluids with biochemical and clinical correlation.

\section{Methods}

Setting: Department of Pathology, Cytopathology section, Karnataka Institute of Medical Sciences, Hubballi, Karnataka, India.

Duration: One and half year, from January 2019 to June 2020.

Type of study: Institution-based prospective observational and analytical cross-sectional study.

Sampling methods: Consecutive 150 fluid samples matching the inclusion and exclusion criteria were taken.

Sample size: A total of 150 body fluid samples were subjected to evaluation by both $\mathrm{CS}$ and $\mathrm{CB}$ methods.[There is no particular disease for calculating the sample size. All the specimen coming to Pathology Department, Cytology section were included in the present study, satisfying inclusion and exclusion criteria.]

Inclusion criteria: All the 150 consecutive pleural, ascitic fluid, Pouch of Douglas fluid and Synovial fluid samples received in the department, during the study period for the diagnostic purpose were included in this study.

Exclusion criteria: All other fluids except pleural, ascitic fluid, Pouch of Douglas fluid and Synovial fluid, clotted fluid specimens, specimens less than $10 \mathrm{ml}$ and sub-optimally preserved fluids were excluded from the study. 
Data collection procedure: Relevant information regarding age, sex, presenting clinical features, radiological and Biochemical findings were recorded.

Type of fluid, CS findings, and CB findings, final diagnosis were assessed.

Each fresh fluid specimen s divided into two equal parts. One part was subjected to the conventional smear cytology technique and the other part for the cell block technique.

In Conventional Smear Technique: The $5 \mathrm{ml}$ sample was centrifuged at $2500 \mathrm{rpm}$ for 10 minutes. A minimum of 3 smears were prepared from the sediment. One smear was prepared after air drying and it was stained with the wright's stain. The other two smears were immediately fixed in $95 \%$ alcohol, and were stained with the Papanicolaou stain and Haematoxylin-Eosin stain.

In Cell Block Technique: Second test tube with $5 \mathrm{ml}$ sample was subjected to fixation in $10 \%$ alcohol -formalin 1:1 proportion for one hour. After fixation, it will be centrifuged at $3000 \mathrm{rpm}$ for $15 \mathrm{~min}$. After centrifugations the supernatant is discarded and $3 \mathrm{ml}$ of fresh alcohol-formalin is added to the sediment and is kept for minimum of 24 hours, and will be sent for routine histopathological processing the fixed tissue will be sectioned like any histopathology tissue and put on slides and stained with Hematoxylin and Eosin. Whenever necessary special histochemical stains will be used.

Morphological criteria including cellularity, arrangement of cells, nuclear and cytoplasmic details were put together and used for the categorization of the fluid specimens. Patients were diagnosed through clinical history, laboratory tests, radiological examination, cytological examination, cell block technique, and subsequently, each was categorized by Benign, suspicious for malignancy and Malignant effusion.

Data analysis: A comparative evaluation of the results of $C S$ versus the $C B$ techniques was conducted. Statistical analysis was done by using SPSS software. Chi-square test was used.

Ethical consideration and permission: This study was conducted on specimens sent for the routine CS cytology. [Ethical consideration and permission not necessary, as the study is not conducted directly on patients.]

\section{Results}

\section{Distribution of Cases: [Table 1]}

All the 150 fluid specimens were subjected to the $\mathrm{CS}$ and the $\mathrm{CB}$ techniques. It was then observed that out of total 150 specimens studied, majority of samples ie 97 cases $(64.66 \%)$ were of pleural fluid, followed by 48 cases(32\%) were of ascitic fluid, 4 cases $(2.66 \%)$ were from pouch Douglas fluid and 1case $(0.7 \%)$ was of synovial fluid, as shown in the (Table 1 ) below.

Table-1: Type of Fluid distribution of patients studied.

\begin{tabular}{|l|l|l|}
\hline \multicolumn{1}{|c|}{ Type of Fluid } & \multicolumn{1}{c|}{ No. of Patients } & \multicolumn{1}{c|}{$\%$} \\
\hline Pleural fluid & 97 & 64.66 \\
\hline Ascitic fluid & 48 & 32.0 \\
\hline Pouch of Douglas fluid & 4 & 2.66 \\
\hline Synovial fluid & 1 & 0.7 \\
\hline Total & 150 & 100.0 \\
\hline
\end{tabular}

\section{Age Distribution of Cases: [Table 2]}

Maximum numbers of cases were recorded in the 5th and 6th decades, as shown in the (Table 2) below.

With a mean age group of 53.32 (Mean \pm SD: 53.32 \pm 14.90$)$.

Table-2: Age distribution of patients studied.

\begin{tabular}{|l|l|l|}
\hline \multicolumn{1}{|c|}{ Age In Years } & \multicolumn{1}{c|}{ No. Of Patients } & \multicolumn{1}{c|}{$\%$} \\
\hline$<20$ & 3 & 2.0 \\
\hline $20-30$ & 8 & 5.3 \\
\hline $31-40$ & 23 & 15.3 \\
\hline $41-50$ & 31 & 20.7 \\
\hline $51-60$ & 37 & 24.7 \\
\hline $61-70$ & 34 & 22.7 \\
\hline$>70$ & 14 & 9.3 \\
\hline Total & 150 & 100.0 \\
\hline
\end{tabular}

Mean \pm SD: $53.32 \pm 14.90$

\section{Gender Distribution: [Table 3]}

Males comprised $53.3 \%$ of cases with a number of 80 cases and females were $46.7 \%$ with 70 cases, as shown in the table 3 below.

Table-3: Gender distribution of patients studied.

\begin{tabular}{|l|l|l|}
\hline \multicolumn{1}{|c|}{ Gender } & \multicolumn{1}{c|}{ No. Of Patients } & \multicolumn{1}{c|}{$\%$} \\
\hline Female & 70 & 46.7 \\
\hline Male & 80 & 53.3 \\
\hline Total & 150 & 100.0 \\
\hline
\end{tabular}


Distribution of number of fluid specimen among gender \& type by conventional smear based diagnosis: [Table 4]

It was seen that 54 (36\%) of male and $43(28.66 \%)$ of female patients had pleural effusion; 23 (15.33\%) of male and $25(16.66 \%)$ of females had ascitic fluid; $04(2.66 \%)$ specimen were from pouch of Douglas fluid, all were from female patients. And $01(0.66 \%)$ of synovial fluid from male patient. Amongst the total number of specimen studied, Males predominantly had pleural effusion and females had ascitic effusion. Four specimens of from pouch of Douglas fluid were received and all were from female patients. And one specimen of synovial fluid was received which was from male patient, as shown in the (Table 4) below.

Table 4: Distribution of number of fluid specimen among gender \& type by conventional smear based diagnosis.

\begin{tabular}{|c|c|c|c|c|c|}
\hline & Sample & Male & Female & Transudate & Exudate \\
\hline Pleural fluid & $\begin{array}{l}97 \\
(64.66 \%)\end{array}$ & $54(36 \%)$ & $\begin{array}{l}43 \\
(28.66 \%)\end{array}$ & $61(67 \%)$ & $\begin{array}{l}37 \\
(62.7 \%)\end{array}$ \\
\hline Ascitic fluid & $48(32 \%)$ & $\mid \begin{array}{l}23 \\
(15.33 \%)\end{array}$ & $\begin{array}{l}25 \\
(16.66)\end{array}$ & $29(31.9 \%)$ & $\begin{array}{l}18 \\
(30.5 \%)\end{array}$ \\
\hline $\begin{array}{l}\text { Pouch of Douglas } \\
\text { fluid }\end{array}$ & $\mid \begin{array}{l}04 \\
(2.66 \%)\end{array}$ & $00(0 \%)$ & $04(2.66)$ & $00(0 \%)$ & $4(6.8 \%)$ \\
\hline Synovial fluid & $01(0.7 \%)$ & $\begin{array}{l}01 \\
(0.66 \%)\end{array}$ & $00(0 \%)$ & $1(1.1 \%)$ & $0(0 \%)$ \\
\hline Total & $\begin{array}{l}150 \\
(100 \%)\end{array}$ & $78(52 \%)$ & $72(48 \%)$ & $91(60.66 \%)$ & $\mid \begin{array}{l}59 \\
(39.33 \%)\end{array}$ \\
\hline
\end{tabular}

Of the 150 fluids studied, 91 were Transudative effusions. Smears from such fluids showed only sparse cellularity comprising of scattered inflammatory cells and few benign mesothelial cells. Causes such as cirrhosis, congestive cardiac failure, nephrotic syndrome, hypoproteinaemia were observed as per clinical history. Out of 91 Transudative effusion, cases $61(67 \%)$ belonged to pleural effusion, 29(31.9\%) belongs to ascitic effusion and $1(1.1 \%)$ belongs to Synovial fluid, as shown in the (Table 4) above.

Of the total 150 fluid specimens, 59 were Exudative effusions. It showed predominantly neutrophil, lymphocyte, macrophage, few RBCs occasional necrotic material and mesothelial cells showing range of reactive changes. Gaps and windows were also seen between adjacent reactive cells. Causes were acute infection, tuberculosis, malignancy, trauma, rheumatoid arthritis and subphrenic abscess.
Out of 59 Exudative effusion, 37(62.7\%) cases belonged to pleural effusion, $18(30.5 \%)$ belongs to ascitic effusion and $04(6.8 \%)$ belongs to fluid from pouch of Douglas as shown in the (Table 4) above. Total of $122(81.33 \%)$ fluid specimens were categorized as benign effusion by conventional smear method; $86(70.49 \%)$ specimens belonged to pleural effusion; $35(28.68 \%)$ specimens belonged to ascitic fluid, 01(0.81\%)was from synovial effusion. $16(10.66 \%)$ fluid specimens were categorized as malignant effusion by CS method, 05 (31.25\%) specimens belonged to Pleural effusion and $07(43.75 \%)$ specimens belonged to ascitic effusion and $04(25 \%)$ were from Pouch of Douglas fluid. 12(085) fluid specimens were categorized as suspicious of malignant effusion by CS method; out of these $07(58.33 \%)$ specimens belonged to pleural effusion and $05(41.66 \%)$ specimens belonged to ascitic effusion as shown in (Table 5 ) below.

Table-5: Distribution of number of fluid specimen among benign, suspicious of malignant \& malignant effusion by conventional smear (cs) based diagnosis.

\begin{tabular}{|l|c|l|l|l|}
\hline & Sample & \multicolumn{1}{|c|}{ Benign } & Suspicious & Malignant \\
\hline Pleural fluid & $98(65.33 \%)$ & $86(70.49 \%)$ & $07(58.33 \%)$ & $05(31.25 \%)$ \\
\hline Ascitic fluid & $47(31.33 \%)$ & $35(28.68 \%)$ & $05(41.66 \%)$ & $07(43.75 \%)$ \\
\hline Pouch of Douglas fluid & $04(2.66 \%)$ & $00(0 \%)$ & $00(0 \%)$ & $04(25 \%)$ \\
\hline Synovial fluid & $01(0.66 \%)$ & $01(0.81 \%)$ & $00(0 \%)$ & $00(0 \%)$ \\
\hline Total & $150(100 \%)$ & $122(81.33 \%)$ & $12(08 \%)$ & $16(10.66 \%)$ \\
\hline
\end{tabular}

By the CB method, additional 12 cases were detected as malignant, that is a $08 \%$ more diagnostic yield for malignancy. These 12 fluid specimens were reported as suspicious for malignancy by CS method previously. Thus, cellular yield which was obtained by the $\mathrm{CB}$ method was more when it was compared to the one which was obtained by the CS method. After CB method was applied, diagnostic sensitivity and specificity increased, as shown in the [Table 6] below. Finally, after CB method, of a total of 28 cases of malignant effusions, 12 belonged to pleural effusion and 12 to ascitic effusion,04 belongs to the pouch of Douglas fluid. The $P$ value for $C S$ and $C B$ is $P<0.001$ which is statistically significant.

Table-6: CS diagnosis distribution in relation to CB diagnosis of patients studied.

\begin{tabular}{|l|l|l|l|}
\hline No & Diagnostic Category & CS Method (Total) & CB Method (Total) \\
\hline 1 & Benign & $122(81.3 \%)$ & $122(81.3 \%)$ \\
\hline 2 & Suspicious for malignancy & $12(8 \%)$ & $00(0 \%)$ \\
\hline 3 & Malignant & $16(10.7 \%)$ & $28(18.7 \%)$ \\
\hline 4 & Total & $150(100 \%)$ & $150(100 \%)$ \\
\hline
\end{tabular}


$\mathrm{P}<0.001$

Of the 150 fluids studied, 122 (81.3\%) cases were diagnosed as benign by conventional smear, among which $37(62.7 \%)$ cases were Exudate and 85(93.4\%) cases were Transudate. 16(10.7\%) cases were diagnosed as Malignant, in which all were Exudate. $12(8 \%)$ cases were diagnosed as suspicious for malignancy among which $6(10.2 \%)$ cases were Exudate and 6(10.2\%) cases were Transudate.

And among 122 benign cases diagnosed by cell block method $37(62.7 \%)$ cases were Exudate and 85(93.4\%) cases were Transudate. And 28 (18.7\%) cases were diagnosed as Malignant in which $22(37.3 \%)$ cases were Exudate and $6(6.6 \%)$ cases were Transudate.

Association of transudate and exudate in conventional smear diagnosis and cell block diagnosis of both Benign and Malignant lesions was statistically significant with $P$ value $<0.001$.as shown in the [table 7] below.

Table-7: Association of clinical variables in relation to exudate/transudate of patients studied.

\begin{tabular}{|c|c|c|c|c|}
\hline \multirow[t]{2}{*}{ Variables } & \multicolumn{2}{|c|}{ Bio Chemistry } & \multirow[t]{2}{*}{ Total $(n=150)$} & \multirow[t]{2}{*}{$P$ value } \\
\hline & Exudate $(\mathrm{N}=59)$ & Transudate $(\mathrm{N}=91)$ & & \\
\hline \multicolumn{5}{|c|}{ CS Diagnosis } \\
\hline - Benign & $37(62.7 \%)$ & 85(93.4\%) & $122(81.3 \%)$ & \multirow[t]{3}{*}{$<0.001$} \\
\hline - Malignant & $16(27.1 \%)$ & $0(0 \%)$ & $16(10.7 \%)$ & \\
\hline SFM & $6(10.2 \%)$ & $6(6.6 \%)$ & $12(8 \%)$ & \\
\hline \multicolumn{5}{|c|}{ CB Diagnosis } \\
\hline - Benign & $37(62.7 \%)$ & 85(93.4\%) & $122(81.3 \%)$ & \multirow[t]{2}{*}{$<0.001$} \\
\hline - Malignant & $22(37.3 \%)$ & $6(6.6 \%)$ & $28(18.7 \%)$ & \\
\hline
\end{tabular}

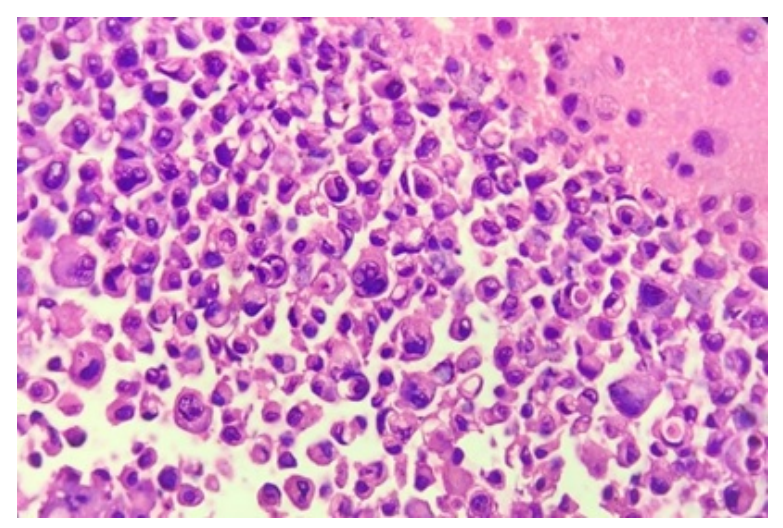

Fig. 1: Photomicrograph of cell block of case of secondary deposits to lung showing signet ring cells and features of malignancy. ( $H$ and $E$ 40x)

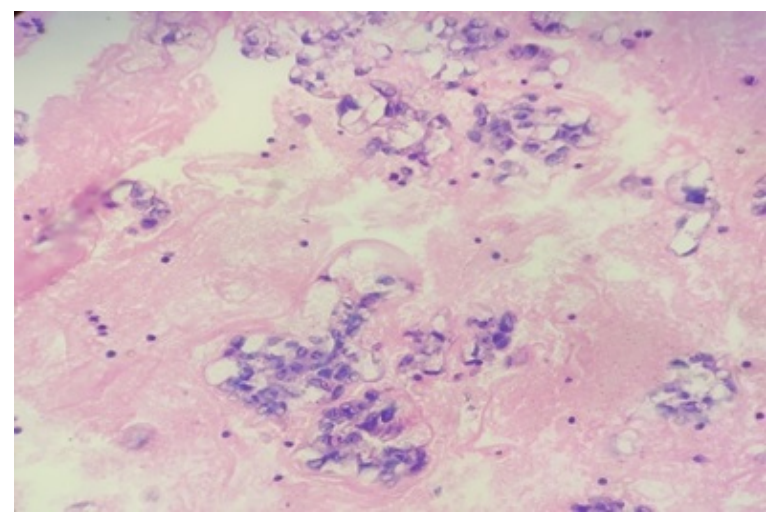

Fig 2: Photomicrograph of cell block showing adenocarcinoma deposits. A case of ca ovary. ( $H$ and $E$ 40x)

\section{Discussion}

The cytological examination of serous effusions is of paramount importance in diagnostic, therapeutic and prognostic implications. It is important not only in the diagnosis of malignant lesions, but it also helps in the staging and the prognosis of these lesions [6]. The malignant cells in the pleural or the ascitic fluids were almost always indicative of metastatic tumours, as primary malignancies which arose from the mesothelial cell lining were rare. When a primary malignancy was present, the tumour cells were usually found to be numerous and they were seen in clusters. A positive effusion for malignant cells is an important prognostic indicator in oncologic patients. [7]. The examination of body fluids for the presence of malignant cells has been accepted as a routine laboratory procedure, not only for the detection of unsuspected cancers, but also for the detection of metastasis of an unknown primary origin [8].

The cell population in sediment of body fluid represents a much larger surface area than obtained by needle biopsy. Cell blocks prepared from residual tissue fluid can be used as adjuncts to smear for establishing a more definitive cytopathological diagnosis. The technique is simple, safe, costeffective and reproducible even in resource limited settings [9]. Cell blocks provided the best milieu for morphologic interpretation, with less background staining and results that most closely approximated those reported in the surgical pathology literature [10].

Beale introduced the paraffin-block method for serous effusions in 1895 [11]. 
In 1896, Bahrenberg first described the cell block technique and it was commonly used after Mandlebaum reported the finding of actinomyces in a cell block [12]. In this study, an attempt was made to prepare and to analyse both the CS and the $\mathrm{CB}$ which were prepared by using $10 \%$ alcoholformalin as a fixative, from the same specimen.

The CBs which are prepared from the residual tissue and fluids can be particularly useful for the identification of the tumours that cause diagnostic difficulties on smears. This technique is simple, reproducible and safe. Further, the effectiveness of the cellblock lies in the availability of the diagnostic material for the further histological examination, histochemistry and IHC studies for a better classification of the tumour and for the identification of infectious causes by using microbiologic stains $[13,14]$.

All the 150 fluid specimens were subjected to the CS and the CB techniques. It was then observed that out of total 150 specimens studied, majority of samples ie 97 cases $(64.66 \%)$ were of pleural fluid, followed by 48 cases (32\%) were of ascitic fluid, 4 cases $(2.66 \%)$ were from pouch of Douglas fluid and 1 case $(0.7 \%)$ was of synovial fluid (Table 1 ). Maximum numbers of cases were recorded in the 5 th and 6th decades. (Table 2). Males comprised $53.3 \%$ of cases with a number of 80 and females were $46.7 \%$ with 70 cases. (Table 3 ). Of the 150 fluids studied, 91 were Transudative effusions, 59 were Exudative effusions. (Table 4).

Total 122 (81.33\%) fluid specimens were categorized as benign effusion by conventional smear method; $86(70.49 \%)$ specimens belonged to pleural effusion; $35(28.68 \%)$ specimens belonged to ascitic fluid, 01(0.81\%)was from synovial effusion, $16(10.66 \%)$ fluid specimens were categorized as malignant effusion by CS method, 05 (31.25\%) specimens belonged to Pleural effusion and $07(43.75 \%)$ specimens belonged to ascitic effusion and $04(25 \%)$ were from Pouch of Douglas fluid. 12(085) fluid specimens were categorized as suspicious of malignant effusion by CS method; $07(58.33 \%)$ specimens belonged to pleural effusion and $05(41.66 \%)$ specimens belonged to ascitic effusion (Table 5).

By the CB method, additional 12 cases were detected as malignant, that is a $08 \%$ more diagnostic yield for malignancy. These 12 fluid specimens were reported as suspicious for malignancy by CS method previously.
Thus, by using $\mathrm{CB}$ method, $08 \%$ additional diagnostic yield could be obtained, which is in line with the study done by Thapar $M$ et al whose study showed $13 \%$, Richardson et al showed $12 \%$ and Liu et al showed $12 \%$ increase in diagnosis $[15,16,17]$. The CB method uses histological techniques for processing and thus offers a major advantage. Multiple sections of the same material may be processed for routine stains and for special stains that may serve for immunohistochemistry and for identification of mucin, melanin or other cell products and identification of bacteria and fungi. $C B$ technique is simple, safe and reproducible. The material often contains valuable diagnostic evidence and tissue fragments that cannot be processed by cytological technique. Malignant cells not present on the smears often are found within the cell block. Cases that are suspicious or equivocal on the smears can be diagnosed definitively with the aid of a cell block preparation [18].

\section{Limitations of the study}

Not all the fluids sent for analysis were subjected for Cell Block. Only the fluids sent for cytology section and requested for cytological study were included in the present study.

If all the fluids would have been subjected to cell block along with conventional smear, more number of malignancies would have been diagnosed with definitive diagnosis. Along with the cytology and biochemical examination, clinical, radiological and microbiological findings would improve the accuracy of diagnosis and assisting the better treatment outcome of the patient.

CB method is an excellent complementary tool for improving cytodiagnosis in effusions. The additional yield for the malignancy was found to be $8 \%$ more by $\mathrm{CB}$ as compared to that obtained by CS method. Therefore, we can reduce false negative results and increase diagnostic sensitivity and specificity. A combined use of smears and cell block is recommended to raise further diagnostic accuracy.

\section{What does the study add to the existing knowledge?}

Earlier only conventional cytology smears were used for studying morphology, inflammatory effusions, malignant and non malignant cases. Cell block will not only help in diagnosing the malignancy but also help in type and typing the malignancy. 
The current study reports the diagnostic efficiency of the cell block method to be superior to that of conventional smear alone. Hence cell block preparation should be routinely incorporated. Cell block sections can also be used for special stains and immunohistochemistry.

\section{Author's contribution}

All the authors, Dr. Rajesh H. Chandan, Dr. Sumana, Dr. Purushotham Reddy. Contributed equally to the conduct of the study and in the preparation of the manuscript.

\section{Reference}

01. Kumar, Abbas, Aster. Robbins and Cotran Pathologic Basis of Disease. 9th ed, Philadelphia, Saunders Elsevier. 2015.

[Crossref]

02. Leopold. Koss' Diagnostic Cytology and its Histopathologic Bases. 5th ed, Philadelphia, J B Lippincott. 2006.

[Crossref]

03. Marluce Bibbo, David Wilbur. Comprehensive Cytopathology. 4th ed, Saunders Elsevier. 2015. [Crossref]

04. Kushwaha $R$, Shashikala $P$, Hiremath $S$, Basavaraj HG. The cells in the pleural fluid and their value in the differential diagnosis. J Cytol. $2008 ; 25 ; 138-43$.

DOI: $10.4103 / 0970-9371.50799$ [Crossref]

05. Shivakumarswamy U, Arakeri SU, Mahesh H Karigowdar $\mathrm{MH}$, Yelikar BR. Diagnostic utility of the cell block method versus the conventional smear study in pleural fluid cytology. J Cytol. 2012;29;11-15.

DOI: $10.4103 / 0970-9371.93210$ [Crossref]

06. Dekker A, Bupp PA. The cytology of serous effusions- An investigation into the usefulness of cell blocks versus smears. Am J Clin Pathol. $1978 ; 70 ; 855-60$.

[Crossref]

07. Sears D, Hajdu SI. The cytologic diagnosis of malignant neoplasms in pleural and peritoneal effusions. Acta Cytol. 1987;31;85-97.

[Crossref]
08. Wong JW, Pitlik D, Abdul-Karim FW. Cytology of pleural, peritoneal and pericardial fluids in children- A 40 years summary. Acta Cytol. $1997 ; 41 ; 467-73$.

doi: $10.1159 / 000332540 \quad$ [Crossref]

09. Ghosh I, Dey SK, Das A, Bhattacharjee D, Gangopadhyay S. Cell block cytology in pleural effusion. J Indian Med Assoc. 2012;110(6)390396.

[Crossref]

10. Fetsch PA, Simsir A, Brosky K, Abati A. Comparison of three commonly used cytologic preparations in effusion immunocytochemistry. Diagn Cytopathol. 2002;26;61-66.

DOI: $10.1002 / d c .10039$ [Crossref]

11. Leung SW, Bedard YC. Methods in Pathology- A simple mini block technique for cytology. Mod Pathol. 1993;6;630-32.

[Crossref]

12. Velios F, Griffin J. Examination of the body fluids for tumor cells. Am J Clin Pathol. 1954;24;67681.

DOI: $10.1093 /$ ajcp/24.6.676 [Crossref]

13. Price BA, Ehya $H$, Lee $\mathrm{JH}$. The significance of the pericellular lacunae in the cell blocks of effusions. Acta Cytol. 1992;36;333-37.

[Crossref]

14. Kung IT, Yuen RW, Chan JK. Technical notesThe optimal formalin fixation and the processing schedule of the cell blocks from the fine needle aspirates. Pathology. $1989 ; 21 ; 143-45$.

doi: $10.3109 / 00313028909059552$ [Crossref]

15. Thapar M, Mishra RK, Sharma A, Goyal V, Goyal V. Critical analysis of cell block versus smear examination in effusions. J Cytol. 2009;26(2)60-4.

DOI: $10.4103 / 0970-9371.55223$ [Crossref]

16. Richardson HL, Koss LG, Simon TR. Evaluation of concomitant use of cytological and histological technique in recognition of cancer in exfoliated material from various sources. Cancer. $1955 ; 8 ; 948-50$.

DOI: $\quad 10.1002 / 1097-0142(1955) 8: 5<948$ : :aidcncr2820080515>3.0.co;2-m [Crossref] 
17. Liu K,Dodge K,Glassgow BJ, Layfield LJ. Comparison of smears, cytospin \& cell block preparation in diagnostic \& cost effectiveness. Diagn cytopathol. 1998;19(1)70-4.

DOI:

$10.1002 /($ sici $) 1097-$

0339(199807)19:1<70: :aid-dc15>3.0.co;2-5 [Crossref]
18. Keyhani-Rofagha S, Vesey-Shecket $M$. Diagnostic value, feasibility, and validity of preparing cell blocks from fluid-based gynecologic cytology specimens. Cancer Cytopathol. 2002; 96;204-209.

DOI: $10.1002 /$ cncr.10716 [Crossref] 